\title{
Significance of Nasal Septum Angulation and Its Association with Rhinosinusitis Symptom Scores
}

\section{Nazal Septum Angulasyonunun Önemi ve Rinosinüzit Semptom Skorları ile Ilişkisi}

\author{
Norhafiza Mat LAZIM $\odot$, Abdul Mokhti ABDULLAH $\odot$, Baharudin ABDULLAH $\odot$, Zul Izhar Mohd ISMAIL $\odot$
}

Ethics Committee Approval: This study approved by the University Sains Malaysia, Human Research Ethic Committee, USM/JEPeM/140254.

Conflict of interest: The authors declare that they have no conflict of interest.

Funding: None.

Informed Consent: Informed consent was taken from the patients enrolled in this study.
Cite as: Lazim N.M, Abdullah A.M, Abdullah B, Ismail ZIM. Significance of nasal septum angulation and its association with rhinosinusitis symptom scores. Medeniyet Med J. 2019;34:333-9.

\begin{abstract}
Objective: The aim of the study was to determine the association of angulation of nasal septum with the severity of rhinosinusitis as measured by symptom score and Visual Analog Score (VAS).

Method: The study was performed as a cross sectional study conducted at two different centres in Malaysia. Ninety-eight patients who were diagnosed with rhinosinusitis and fulfilled the selection criteria were assessed as for the symptom score and VAS and the measurement of angulation of nasal septum was performed through a coronal view of CT paranasal sinuses in bone window setting at osteomeatal complex level.

Results: The result obtained from one-way ANOVA test revealed a significant association between category of severity of septal angulation and the symptom score of rhinosinusitis $(p=0.025)$. In addition, the result obtained from one-way ANOVA test also revealed a significant association between category of severity of septal angulation and the VAS of rhinosinusitis $(p<0.05)$.

Conclusion: Severity of nasal septum angulation may be significantly associated with severity of rhinosinusitis based on symptom score and VAS. These findings could be used in tailored management of patient with rhinosinusitis especially during functional endoscopic sinus surgery.
\end{abstract}

Keywords: Nasal septal angulation, rhinosinusitis, symptoms score, endoscopic sinus surgery

öz

Amaç: Bu çalışmanın amacı, nazal septum açısının rinosinüzit şiddeti ile ilişkisini semptom skoru ve Visual Analog Score (VAS) ile belirlemekti.

Yöntem: Araştırma, Malezya'daki iki farklı merkezde kesitsel çalışma olarak yürütüldü. Rinosinüzit tanısı alan ve çalışma protokolüne uyan doksan sekiz hasta semptom skoru ve VAS açısından değerlendirildi ve koronal planda kemik penceresinde çekilen paranazal sinus tomografisi ile osteomeatal kompleks seviyesinde nazal septumun orta hatla olan açısının (angulasyon) ölçümü yapıldı.

Bulgular: Tek yönlü ANOVA testinin sonucu, septal angulasyonu ile rinosinüzit semptom skoru arasında anlamlı bir ilişki bulundu $(p=0,025)$. Ek olarak, tek yönlü ANOVA testinin sonucu aynı zamanda septal angulasyonun ciddiyet kategorisi ile rinosinüzitin VAS'ı arasında da anlamlı bir ilişki olduğunu ortaya koydu $(p<0,05)$.

Sonuc: Nazal septum angulasyonunun şiddeti, semptom skoru ve VAS temelinde rinosinüzitin ciddiyeti ile ilişkili olabilir. Bu bulgular, rinosinüzitli hastaların özellikle fonksiyonel endoskopik sinus cerrahisi ile tedavisi sırasında dikkate alınabilir.

Anahtar kelimeler: Nazal septal angulasyon, rinosinüzit, semptom skoru, endoskopik sinüs cerrahisi
Received: 30 October 2019

Accepted: 7 December 2019 Online First: 26 December 2019

Corresponding Author: N.M. Lazim

ORCID: 0000-0002-2367-1814 Department of OtorhinolaryngologyHead \& Neck Surgery, School of Medical Sciences, Universiti Sains Malaysia, 16150 Kubang Kerian, Kelantan, Malaysia. norhafiza@usm.my

A.M. Abdullah

ORCID: 0000-0003-0283-2030 Hospital Melaka, Jalan Mufti Haji Khalil, Department of Otorhinolaryngology-Head \& Neck Surgery, Melaka, Malaysia

B. Abdullah ORCID: 0000-0001-9138-9215 Universiti Sains Malaysia, Health Campus, Department of Otorhinolaryngology-Head \& Neck Surgery, Kelantan, Malaysia

Z.I.M. Ismail ORCID: 0000-0002-3732-8240 Universiti Sains Malaysia, Health Campus, Department of Anatomy, Kelantan, Malaysia 


\section{INTRODUCTION}

Rhinosinusitis is a significant health problem that has been diagnosed more frequently than all of the other respiratory diseases in adults globally. Pathophysiology-based explanation of rhinosinusitis remains elusive. Multiple factors that have been associated with rhinosinusitis include allergy, bacteria, virus, superantigens and biofilms ${ }^{1,2}$. The quest for a single and conclusive aetiology continues. The investigations have led to postulation that multiple factors may exist together and cause chronic rhinosinusitis. Most experts have postulated that chronic rhinosinusitis may be due to a syndrome of inflammation and impaired mucociliary clearance. Anatomic abnormalities were well recognized as significant factors involving in the pathogenesis of rhinosinusitis. Nasal anatomic abnormalities that have been identified in the pathogenesis of rhinosinusitis include deviated nasal septum, uncinate process deviation, concha bullosa and paraseptal structural abnormalities ${ }^{3-5}$. These abnormalities have led to the obstruction of the osteomeatal unit and subsequently causing the development of rhinosinusitis.

Many studies have documented the association between nasal septum deviation and chronic rhinosinusitis especially in the Middle Eastern, African and European populations ${ }^{4-7}$. However there was no study specifically documenting the relationship between the nasal septum angulation and the severity of rhinosinusitis, especially in the Asian population. This is pivotal since nasal septal angulation would influence the management of rhinosinusitis patients. In addition, it is also very prudent to determine the severity of nasal septal angulation before performing the very first surgical intervention, such as septoplasty and functional endoscopic sinus surgery. A very comprehensive evaluation of the septal angulation is crucial in order to achieve the best surgical outcomes without requiring reoperation.

\section{MATERIAL and METHODS}

The study protocol was approved by the Human Research Ethics Committee(USM/JEPeM/140254), School of Medical Sciences, Universiti Sains Malaysia and Medical Research and Ethical Committee, Ministry of Health, Malaysia.

Patients older than 18 years, diagnosed with rhinosinusitis (which also include nasal polyp type 1 ), and carrying indications for high resolution CT scan of paranasal sinuses were included in the study. Patients with a history of nasal trauma, septal surgery, septal hematoma, septal perforation, concha bullosa, other prominent nasal abnormalities, and patients with significant sinonasal pathology i.e. sinonasal tumors were excluded from the study.

Symptom scores were adopted from Sandra et al. ${ }^{8}$ which comprise rhinosinusitis symptoms namely facial pain, nasal obstruction, nasal discharge, facial congestion, or postnasal drip, hyposmia, headache, fever, halitosis, ear pain or fullness. Each of the symptoms was scored by the patients between ' 0 ' to '10'. A score of ' 0 ' means no symptom at all and a score of '10' represents the worst symptom experienced. Then the total of the score from each symptom was categorized into either mild (0-30), moderate (31-60) or severe (61-90). Patients recorded their symptom scores based on symptoms that were experienced during their first presentation at the clinic.

Subsequently, patients were assessed for overall disease severity by visual analogue scale scores (VAS) as described by Fokkens et al. ${ }^{9}$. The severity of the disease was categorized as either mild, moderate or severe. This scale was a $10 \mathrm{~cm}$ long line where ' 0 ' represents "not troublesome" and '10' represents "worst thinkable troublesome". The interpretation of the VAS scale scores is as follows: mild, -3 ; moderate, $>3-7$, and severe, $>7-10$ points. In evaluating the severity, patients were asked to mark on the VAS scale the answer 
to the question "How bad are your rhinosinusitis symptoms?" In this study, case report form (CRF) was utilised in order to document the symptom and VAS scores of the patients.

There were two CT scan machines used in this study for the measurement of nasal septal angulation. One CT scan was located at Hospital Sultanah Bahiyah (Somatom Emotion 6, manufactured by Siemens, in November 2004) and the second CT scan was located at Hospital USM (Somatom Definition AS+, manufactured by Siemens in 2009). Both CT scans were used to capture images of the paranasal sinuses in both axial and coronal views with three millimeter thickness. The angulation of nasal septum was evaluated by a radiologist and the principal investigator. The measurement of angulation of nasal septum was performed through a coronal view of CT paranasal sinuses in bone window setting at osteomeatal complex (OMC) level cutting (the landmark used was the maxillary ostium and lateral to anterior 2/3 of middle turbinate). The angulation was measured by using the preinstalled software (Centricity Universal Viewer Zero Footprint, Version 5.0 (SP 6.1) in the computer system located in the Department of Radiology, Hospital USM, Kubang Kerian, or at Hospital Sultanah Bahiyyah Malaysia.

The angulation was determined by the angle between the line drawn from the superior insertion of nasal septum at the crista galli to the inferior insertion of the septum at the maxillary crest level and the line drawn from the superior insertion of the nasal septum at the crista galli to the apex of the septal deviation ${ }^{10}$. The angulation was categorized into normal, mild, moderate and severe

Table 1. Category of DNS angulation (adopted from Mohebbi et al. ${ }^{11}$

\begin{tabular}{ll}
\hline Category & Angulation \\
\hline Normal & $0^{\circ}<$ septal angulation $<5^{\circ}$ \\
Mild & $5^{\circ}<$ septal angulation $<10^{\circ}$ \\
Moderate & $10^{\circ}<$ septal angulation $<20^{\circ}$ \\
Severe & septal angulation $>20^{\circ}$ \\
\hline
\end{tabular}

according to the degrees of angulation of nasal septum $^{11}$ (Table 1 ).

\section{RESULTS}

Ninety-eight patients who were diagnosed with rhinosinusitis and fulfilled the selection criteria were assessed for the symptoms score. In our study, median age of the patients was 44.8 years old. There were Male $(56.12 \%)$ and female (43.88\%) patients were included in the study. The majority of subjects were Malaysian, which represented $81.63 \%$ of the total subjects, followed by Chinese (15.31\%) and Indian (3.06\%) patients. (Table 2). Mean symptom score of the patients in this study was 34.70 ( $S D=9.968)$. Minimum score was 14.0 and maximum score was 65.0 (Figure 1). Mean VAS score of the patients in this study was $5.77(\mathrm{SD}=1.53)$. Minimum score was 2.0 and maximum score was 10.0 (Figure 2). Association

Table 2. Demographic data.

\begin{tabular}{lll}
\hline Demographic data & \multicolumn{1}{l}{ Means (std dev) } & n (\%) \\
\hline Age & & $44.8(12.83)$ \\
& Male & $54(56.1 \%)$ \\
Gender & Female & $44(43.8 \%)$ \\
& Malay & $81(81.6 \%)$ \\
Race & Chinese & $15(15.3 \%)$ \\
& Indian & $2(3.0 \%)$ \\
\hline
\end{tabular}

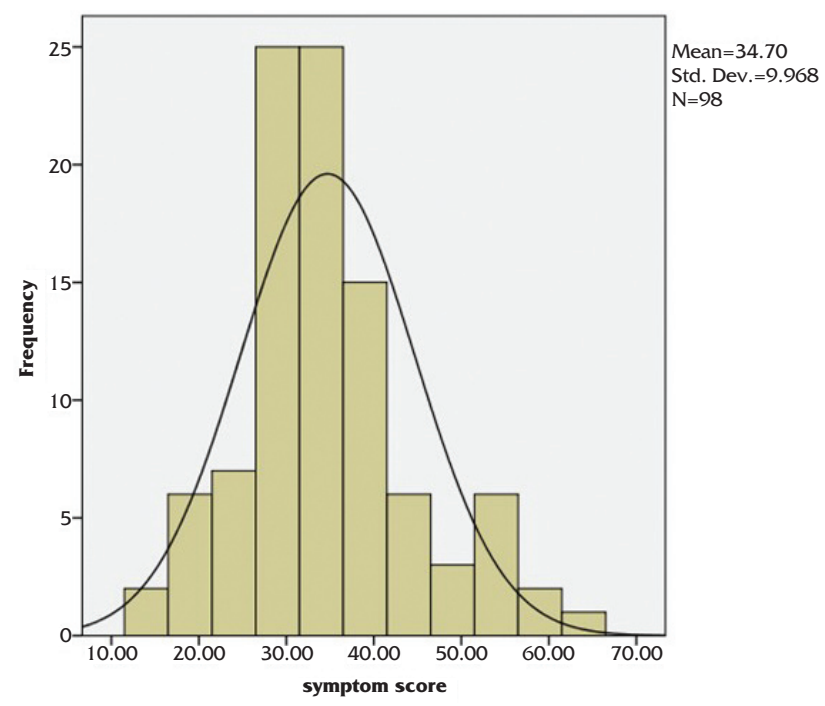

Figure 1. Distribution of the symptom scores. 


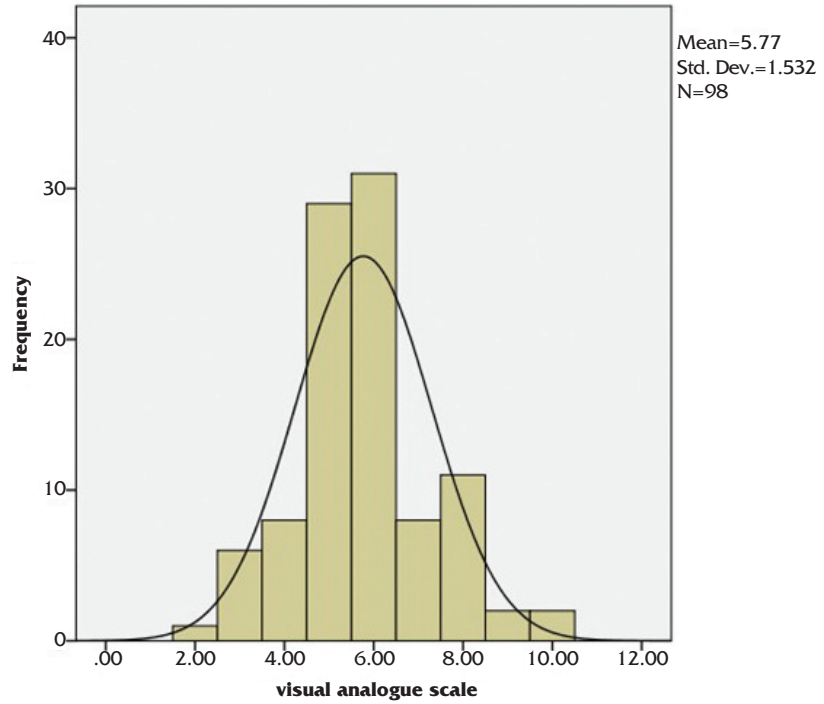

Figure 2. Distribution of score of visual analogue scale score (VAS).

Table 3. Association of different category of severity of nasal septum angulation with the CT scan score of rhinosinusitis.

\begin{tabular}{lllll}
\hline Variables & N & $\begin{array}{l}\text { CT scan score } \\
\text { Mean (SD) }\end{array}$ & (df) \\
& & & $1.79(2.95)$ & 0.172 \\
\hline $\begin{array}{l}\text { Types of angulation } \\
\text { Normal }\end{array}$ & 7 & $9.00(6.11)$ & & \\
$\begin{array}{l}\text { Mild } \\
\text { Moderate }\end{array}$ & 54 & $12.72(6.42)$ & & \\
& 37 & $10.86(5.56)$ &
\end{tabular}

*One-way ANOVA test was not performed with post-hoc test because it is not significant ( $p$-value $=0.172$ ).

Table 4. Association of different types of DNS with the VAS score of rhinosinusitis.

\begin{tabular}{|c|c|c|c|c|}
\hline Variables & $\mathbf{N}$ & $\begin{array}{l}\text { Symptom score } \\
\text { Mean (SD) }\end{array}$ & $\begin{array}{l}\text { F statistics } \\
\text { (df) }\end{array}$ & p-value \\
\hline $\begin{array}{l}\text { Type of deviate } \\
\text { nasal septum }\end{array}$ & & & $0.37(6,91)$ & 0.898 \\
\hline 0 & 1 & 5.00 & & \\
\hline 1 & 31 & $5.77(1.33)$ & & \\
\hline 2 & 12 & $5.33(1.72)$ & & \\
\hline 3 & 26 & $6.00(2.04)$ & & \\
\hline 4 & 15 & $5.93(1.33)$ & & \\
\hline 5 & 5 & $5.60(0.89)$ & & \\
\hline 6 & 8 & $5.50(0.76)$ & & \\
\hline
\end{tabular}

The result from one-way ANOVA test revealed a not significant different between DNS type and VAS score $(p=0.898)$.

of different categories of severity of nasal septum angulation with the CT scan scores of rhinosinusitis are provided in (Table 3 ) and association of different types of DNS with the VAS scores of rhinosinusitis in Table 4.

\section{Distribution of Nasal Septal Angulation}

This study has showed that there were three categories of nasal septal angulation that predominate which were normal, mild and moderate. The representative images of the different categories of nasal septal angulation from our patients are shown in Figures 3 and 4. This study has revealed that $7.1 \%$ of patients had normal category of nasal septal angulation $\left(<5^{\circ}\right)$. There were $55.1 \%$ with mild angulation $\left(5-10^{\circ}\right)$ and $37.8 \%$ with moder-

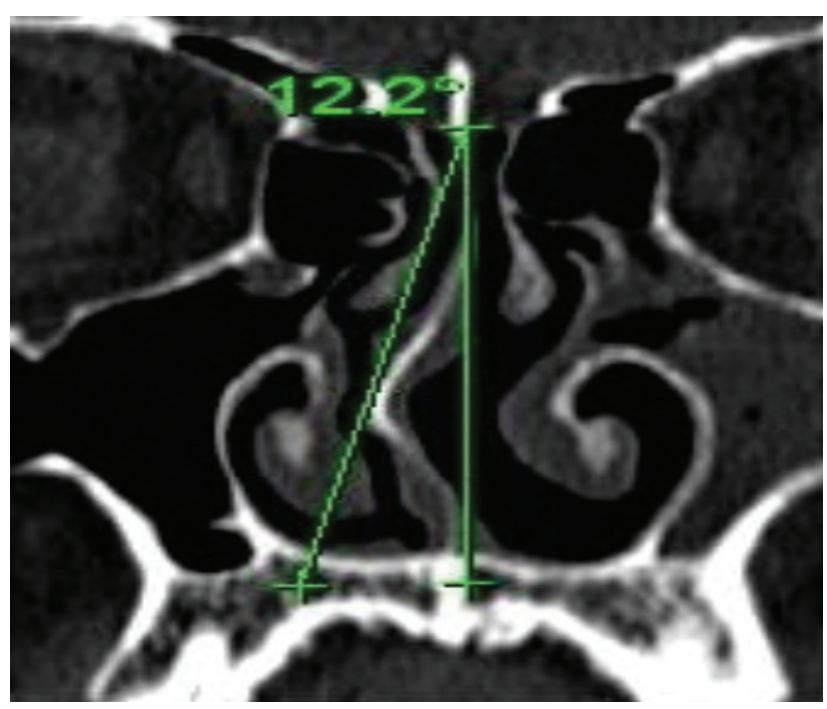

Figure 3. CT paranasal sinus (coronal view) showing nor mal category of nasal septal angulation [Normal $=0^{\circ}<$ septal angulation $<5^{\circ}$.

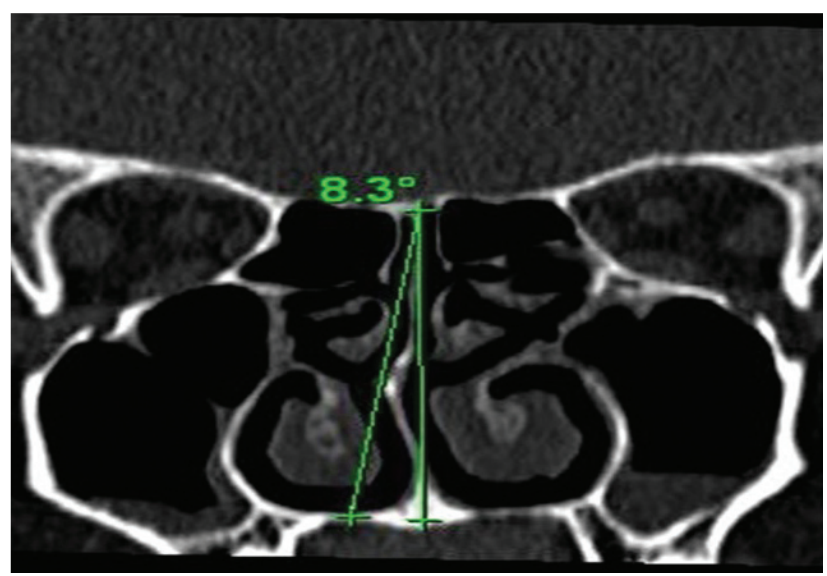

Figure 4. CT paranasal sinus (coronal view) showing mild category of nasal septal angulation $\left(8.3^{\circ}\right)$ [Mild $=5^{\circ}<$ septal angulation $<10^{\circ}$. 
ate angulation of nasal septum (11-20 ). However, none of the patients have severe type of nasal septal angulation $\left(>20^{\circ}\right)$ (Figure 5 ).

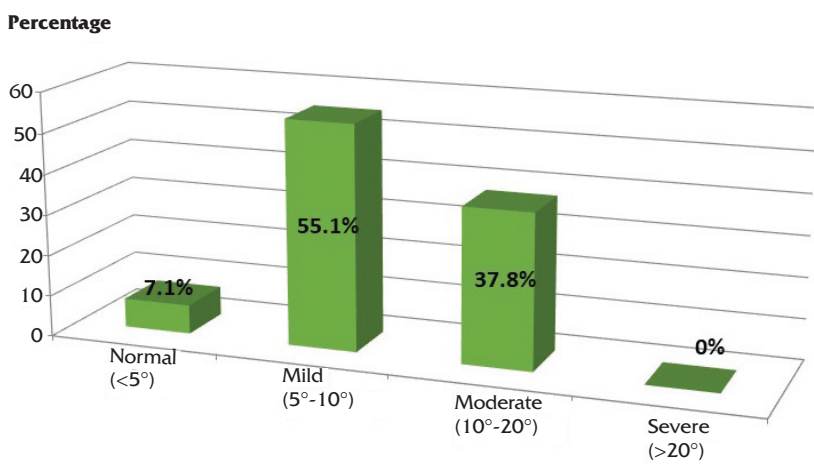

Figure 5. Distribution of degree of nasal septum angulation.

One-way ANOVA test revealed a significant association between category of severity of septal angulation and the symptom score of rhinosinusitis with the p-value of 0.025 . In addition, the result from one-way ANOVA test also revealed a significant association between category of severity of septal angulation and the VAS of rhinosinusitis ( $p$-value $<0.05$ ).

\section{DISCUSSION}

Rhinosinusitis can be defined as a group of disorders which are characterized by inflammation of the mucosa of nose and paranasal sinuses ${ }^{3}$. The Rhinosinusitis Task Force defines the rhinosinusitis as inflammation of both the nose and paranasal sinuses and it is characterized by two or more symptoms, where one of the symptoms can be either nasal blockage/obstruction/congestion or nasal discharge (anterior / posterior nasal drip) with or without presence of facial pain / pressure, and/or reduction or loss of smell; and either endoscopic signs of nasal polyps and / or mucopurulent discharge primarily from middle meatus and / or oedema / mucosal obstruction primarily in middle meatus, and / or computed tomography (CT) scan changes, which can be mucosal changes within osteomeatal complex and / or sinuses?.
Morphologically, there are certain anatomical variations such as deviated nasal septum, uncinate process deviation, paradoxical turbinate, concha bullosa and paraseptal structural abnormalities that have been identified as factors contributing to the obstruction of the osteomeatal unit and the development of chronic rhinosinusitis ${ }^{3-5}$. It has been suggested that deviated nasal septum leads to an increased velocity of nasal airflow ${ }^{12}$. This would result in mucosal drying and disrupt the physiological function of mucociliary clearance. This theory has been supported by the work of Ginzel A et al. ${ }^{13}$ who found a delayed saccharin clearance time in patients with septal deflectio. The third theory was proposed by Bachert et al. ${ }^{14}$ who demonstrated that alterations of maxillary sinus pressure and ventilation with septal deviations in the ostiomeatal complex area. He found diminished antral pressures in association with posterior septal deviations. Meanwhile, Elahi et al. ${ }^{7}$ evaluated 122 patients with sinus disease and found that bilateral sinus diseases and contralateral middle turbinate abnormalities are associated with an increased angulation of septal deviation.

Anatomic abnormalities of the nasal airway are among significant factors contribute to the rhinosinusitis and its pathogenesis. The application of CT imaging in the evaluation of rhinosinusitis together with the advancement in nasal endoscopy contributes further to the improvement in the diagnosis and treatment of rhinosinusitis. In majority of cases, the CT scan of patients with rhinosinusitis will show significant mucosal thickening and presence of polyposis. Subsequently, the search for anatomic abnormalities which caused the osteomeatal complex obstruction and other anatomic variants which impair the mucocilliary clearance continues. Scientists have investigated presence of pneumatized middle turbinates or uncinate process, such as concha bullosa, infraorbital (Haller) cells, sphenoethmoidal (Onodi) cells, enlarged agger nasi cells, paradoxically curved middle turbinates and other anatomic abnormalities that can be found on CT scan images. Impor- 
tantly, recent focus has shifted to finding a nonanatomic aetiology for this critical condition.

Numerous studies have examined the septal deviation abnormality and there was no consensus and strong result. Few literatures described an association between septal deviation and rhinosinusitis, whereas others revealed no such association exists. The majority of studies were small-scale and examined the association indirectly. As an example we can indicate researches investigating the role of a concha bullosa in the development of rhinosinusitis. With a recent understanding and acknowledgement that the pathogenesis of rhinosinusitis is likely to be multifactorial in origin, it is imperative to re-look into the possibility of anatomic variants and abnormalities as contributing factors.

Many studies performed previously have investigated the prevalence of nasal septal deviation and rhinosinusitis. However, most of the studies were performed among the Indian, Middle Eastern and European population. Yousem et al. ${ }^{5}$ had evaluated the morphologic features which contribute to sinusitis and arrived at a conclusion that the patients with evidence of sinusitis on CT scan images had a higher degree of septal deviation. Similarly, Calhoun et al. ${ }^{4}$ examined the paranasal sinus CT scan images of both asymptomatic and symptomatic rhinosinusitis patients and showed a strong correlation existing between septal deviation and sinus diseases. In addition, a systematic and analytical review by Orlandi et al. ${ }^{6}$ has demonstrated significant association between septal deviation and rhinosinusitis. In highly suspicious case of septal angulation, CT scan can be used for detailed evaluation.

In our study, we reviewed CT scan images of 98 patients with rhinosinusitis. The study population comprised of 54 male and 44 female patients. The majority were Malaysian (81.6\%) followed by Chinese (15.3\%) and Indian (3.1\%) patients. If we combined the parameters of the symptom and the VAS scores, most of our patients fell under the moderate category in term of symptom severity and quality of life. It means that our patients recruited in this study actually had a significant symptom of rhinosinusitis with impaired quality of life. This gives strength to this study as the study population was actually represented by a group of symptomatic rhinosinusitis patients.

A study by Danese et al. ${ }^{15}$ has shown that anatomical factors such as ipsilateral deflections of uncinate process, ipsilateral septal ridges or spurs, as well as contralateral septal glass like-deviation are significantly associated with sinusitis. From the study, they revealed possible reasons for the association between DNS and chronic rhinosinusitis. The firstly suggested mechanism involves mechanical obstruction of the osteomeatal complex that was previously highlighted by Stammberger et al. ${ }^{16}$. They demonstrated that the source of obstruction is either from an anatomical deformity or hypertrophy of the nasal mucosa which would further lead to accumulation and stagnation of secretions and predisposition to infection.

Secondly, the association could be due to the aerodynamic factors. It has been suggested that deviated nasal septum increasesvelocity of nasal airflow ${ }^{12}$ which would result in mucosal drying and disrupt the physiological function of mucociliary clearance. This theory is supported by the work of Blaugrund et al. ${ }^{12}$ who found a delayed saccharin clearance time in patients with septal deflection. The third theory was proposed by Bachert et al. ${ }^{14}$ who demonstrated alterations of maxillary sinus pressure and ventilation with septal deviations in the region of the osteomeatal complex. He found diminished antral pressures in association with posterior septal deviations. Moreover, a systematic analytical review by Orlandi et al. ${ }^{6}$ has demonstrated that there is a significant association between septal deviation and rhinosinusitis. Meanwhile, Elahi et al. ${ }^{7}$ evaluated 122 patients with sinus disease and found that an increase in angle of septal deviation is associated with sinus 
disease bilaterally as well as contralateral middle turbinate abnormalities.

\section{CONCLUSION}

This study has showed that the severity of DNS angulation was significantly associated with severity of rhinosinusitis based on symptom and visual analogue scores (VAS) $(p<0.05)$. Thus, the angulation of the nasal septum is needed to be examined meticulously during the first presentation at the ORL clinic with rigorous nasal endoscopy supplemented by CT scan in clinically indicated cases. Consequently, the angulation of deviated nasal septum is imperative to be addressed during the very first endoscopic nasal and septal surgery in order to ensure optimum postoperative outcomes and prevent reoperation and its unwanted complications.

\section{REFERENCES}

1. Tan BK, Schleimer RP, Kern RC. Perspectives on the etiology of chronic rhinosinusitis. Curr Opin Otolaryngol Head Neck Surg. 2010;18:21-6. [CrossRef]

2. Tomassen P, Van Zele T, Zhang N, et al. Pathophysiology of chronic rhinosinusitis. Proc Am Thorac Soc. 2011;8:11520. [CrossRef]

3. Benninger MS, Ferguson BJ, Hadley JA, et al. Adult chronic rhinosinusitis: definitions, diagnosis, epidemiology, and pathophysiology. Otolaryngol Head Neck Surg. 2003;129(3 Suppl):S1-32. [CrossRef]

4. Calhoun $\mathrm{KH}$, Waggenspack GA, Simpson CB, Hokanson JA, Bailey BJ. CT evaluation of the paranasal sinuses in symptomatic and asymptomatic populations. Otolaryngol Head Neck Surg. 1991;104:480-3. [CrossRef]

5. Yousem DM, Kennedy DW, Rosenberg S. Ostiomeatal complex risk factors for sinusitis: CT evaluation. J Otolaryngol. 1991;20:419-24.

6. Orlandi RR. A systematic analysis of septal deviation associated with rhinosinusitis. Laryngoscope. 2010;120:168795. [CrossRef]

7. Elahi $M M$, Frenkiel S, Fageeh N. Paraseptal structural changes and chronic sinus disease in relation to the deviated septum. J Otolaryngol. 1997;26:236-40.

8. Lin SY, Reh DD, Navas-Acien A. Allergic rhinitis, chronic rhinosinusitis, and symptom severity: a population-based study. Int Forum Allergy Rhinol. 2012;2:51-6. [CrossRef]

9. Fokkens WJ, Lund VJ, Mullol J, et al. European Position Paper on Rhinosinusitis and Nasal Polyps 2012. Rhinol Suppl.2012;23:3 p preceding table of contents, 1-298.

10. Harar RP, Chadha NK, Rogers G. The role of septal deviation in adult chronic rhinosinusitis: a study of 500 patients. Rhinology. 2004;42:126-30.

11. Mohebbi A, Ahmadi A, Etemadi M, Safdarian $M$, Ghourchian S. An epidemiologic study of factors associated with nasal septum deviation by computed tomography scan: a cross sectional study. BMC Ear Nose Throat Disord. 2012;12:15. [CrossRef]

12. Blaugrund SM. Nasal obstruction. The nasal septum and concha bullosa. Otolaryngol Clin North Am. 1989;22:291 306.

13. Ginzel A, Illum P. Nasal mucoliliary clearance in patients with septal deviation. Rhinology. 1980;18:177-81.

14. Bachert C. [Experimental studies of the effect of nasal respiratory obstruction on ventilation of the maxillary sinus]. Laryngol Rhinol Otol (Stuttg). 1986;65:250-5. [CrossRef]

15. Danese M, Duvoisin B, Agrifoglio A, Cherpillod J, Krayenbuhl $M$. Influence of naso-sinusal anatomic variants on recurrent, persistent or chronic sinusitis. X-ray computed tomographic evaluation in 112 patients. J Radiol. 1997;78:651-7.

16. Stammberger $\mathrm{H}$, Posawetz W. Functional endoscopic sinus surgery. Concept, indications and results of the Messerklinger technique. Eur Arch Otorhinolaryngol. 1990;247:63-76. [CrossRef] 